\title{
Clinical case: Nursing care of an inmate with thoracic window
}

\author{
Martín-Cocinas Fernández MC, Peñuelas-Olivo G
}

Nurse of Healthcare Team of Murcia I Prison.

\begin{abstract}
Objective: To make a comprehensive assessment of a pacient who has a thoracoscopy or thoracic window that needs wound care. Through the functional patterns of Marjory Gordon and the NANDA taxonomy (North American Nursing Diagnosis Association), NIC (Nursing Interventions Classification), and NOC (Nursing Outcomes Classification). As well as helping the healing and closing time of the wound to be shorter, reducing the risk of infection and improving the quality of life of the patient.

Case presentation: The clinical case of the patient with thoracic window is described. The real and potential diagnoses were established, some objectives or NOC were set and the necessary activities or NIC were carried out to reach them.

Results: On a Likert scale (1 to 5), a wound healing was obtained, from 1 to 3, a level of anxiety, from 3 to 4 , a problem coping, from 3 to 4 , a level of self-care, from 2 to 4 , the promotion of health, from 2 to 4 , and the therapeutic regimen, from 2 to 4 , after one year of follow-up.

Conclusions: The comprehensive approach that should be performed to the patient, not focused only on the reason for the consultation, but assessing the different functional patterns to know which are altered and take into account the evolution of the process and better care and quality improvement of the patient's life.
\end{abstract}

Keywords: thoracostomy, standardized nursing terminology, functional health patterns, cures.

Text received: 31/01/2018

Text accepted: 17/10/2018

\section{INTRODUCTION}

The first thoracic window or thoracostomy was carried out by Elloesser in 1935, to treat a tuberculous empyema in a lung that had not been resected. Claggett and Geraci described a method of open drainage in the post-pneumonectomy empyema, to prevent deforming thoracoplasty. They resected a rib and left the wound open for daily irrigation with a solution of neomycin at $0.25 \%$ until the cavity was sterilised, proposing to subsequently close the thoracostomy. Years later it was abandoned as a treatment, and was taken up again after the Second World War. Vikkula and Konstiainen described a similar method, but by creating a larger window, resecting two or three costal arches. The window was systematically used on bronchopleural fístulae. In 1986, Weissberg considered this technique to be useful for patients with chronic empyema, without necessarily being pneumonectomysed, with or without bronchopleural fístula, leaving the window to close spontaneously ${ }^{1}$.

Wounds commonly occur with tuberculosis, such as recurrent pleurisy, the rupture of a necrotic wound in the pleural cavity or complication of an adjacent artificial pneumothorax, which are often the cause of chronic empyema ${ }^{2}$. A cured pulmonary tuberculosis, in the phase of residual fibrosis, which leads to retractions in the parenchyma with emphysema and bullae in the region of the pleura, is a relatively frequent cause of secondary pneumothorax ${ }^{3}$. However, it is a very rare complication during active pulmonary infection ${ }^{4,5}$.

The thoracic window is a low-incidence surgical technique, recommended as one of the last resort 
therapeutic resources for resolving a pleural or thoracic empyema with cleaning and drainage of the pleural cavity. Managing patients in this situation requires specific nursing care and skills ${ }^{6}$. This type of management and care is uncommon in prisons. It is a low-incidence alternative treatment, and is even more so in the primary healthcare unit of a prison.

Nursing professionals in prisons should carry out comprehensive nursing care on all patients that require a wound to be healed, not just those with chronic processes. Their work cannot be limited to treating the wound, but rather a complete evaluation should be completed with a holistic approach that helps to ensure that interventions being conducted are suitable for the patient, applying the nursing process or methodology, or as Alfaro-LeFevre reminds us: "providing humanistic care focused on efficiently achieving objectives (expected outcomes)" .

The use of the nursing methodology in the prison environment continues to be ignored by most professionals working in this area. According to a study carried out on Primary Healthcare in the Canary Islands ${ }^{8}$, the use of the nursing methodology is related to more computerisation, a larger number of nursing appointments and with the development of more specific training. The most widely used taxonomy in nursing methodology is NANDA, NIC, NOC (N-N-N). They are recognised nursing languages and, according to Royal Decree 1093/2010, which approves the minimum set of data in the clinical reports of the National Health System ${ }^{9}$, they define the ones that should accompany the nursing care reports, such as the nursing diagnoses, objectives and interventions, according to the NANDA, NIC, NOC nomenclature.

This study presents a clinical case of an inmate at the Murcia I Prison, using Marjory Gordon's functional patterns ${ }^{10}$ and the NANDA-NIC-NOC taxonomy ${ }^{11}$, in order to carry out a complete evaluation of the patient and care of the wound, and to try to ensure that the healing process takes place as soon as possible and with minimum complications. Comprehensive care of the patient is considered to be important for obtaining better health outcomes, thereby improving the highly impaired quality of life of patients who are serving sentences in prison.

\section{PRESENTATION OF THE CASE}

The clinical case of an inmate is described, which included highly complex features both for the nursing staff and the medical unit, who presents a thoracic window or thoracostomy window carried out in April 2016. It is a descriptive study of the progress of the wound from when he entered Murcia I Prison (from 11 October 2016 to January 2018), using nursing methodology with the NANDA, NIC, NOC $(\mathrm{N}-\mathrm{N}-\mathrm{N})$ language.

The corresponding authorisation and the patient's informed consent were requested from the General Directorate of Prison Healthcare to carry out the research work.

The case consisted of a 43 year old male, carrier of a thoracostomy window in the thoracic wall after pneumothorax and complex symptoms of tuberculosis, with empyema and persistent leakage. He was treated in Alicante Hospital, while he was interned in Villena Prison, where the thoracic window was opened to clean and drain the pleural cavity, and to assist in the process of filling and healing it. After entry in Murcia I Prison, the patient's symptoms were monitored in the Thoracic Surgery Service of the Virgen de la Arrixaca University Hospital (HUVA) and in the Internal Medicine Service of Murcia. Surgical closure of the cavity was considered to be impossible due to the major risk of severe infection.

\section{History prior to entry in Murcia I Prison}

The patient does not have high blood pressure, diabetes or any known dyslipidemia. He smokes 10 cigarettes/day. He does not consume alcohol, but there is a background of intravenous drug use. The patient's education was basic and he has been in prison for over 23 years. The patient reports that he consumed cocaine because "it calmed him down". He was diagnosed with human immunodeficiency virus (HIV) and hepatitis C virus (HCV) infection in 1990, although he did not voluntarily commence antiretroviral therapy (ART) until 2005, after termination of treatment for pulmonary tuberculosis at the Valencia General Hospital. He also presents pulmonary tuberculosis with several episodes: one in 2004 (treated) and another in January 2016. In January 2016, he asked for voluntary discharge from the General University Hospital General of Elda, after suffering from a pneumothorax that required thoracic drainage. $\mathrm{He}$ 
subsequently presented a complicated pneumothorax that required a pleural drainage tube. The bronchial aspirate taken from a bronchoscopy showed a positive direct smear for Mycobacterium tuberculosis, therefore anti-tuberculosis treatment was initiated. The air leakage and lung collapse continued for over two months, so the decision was made to carry out surgical treatment with parieto-visceral pleural decortication. After surgery, evolution was slow, with no resolution of the lung collapse or the air leak, and so on 19 April 2016 a thoracostomy window was carried out, 20 x $10 \mathrm{~cm}$ left of Eloesser, so as not to depend on the drainage and carry out local healing of the pleural cavity, and the patient was discharged eight days later. In October 2016, he was admitted to the Thoracic Surgery Service of the HUVA to monitor progress and heal the thoracic window. In April 2017, two ulcers were observed in the hiliar area, the cultures of which showed Mycobacterium tuberculosis.

Current treatment: 1 tablet/day (combo) of efavirenz+emtricitabine+tenofovir and 2 tablets/day (combo) of rifampicin+isoniazid, with daily dressings at the Murcia I Prison and every month at the thoracic surgery outpatients unit of the HUVA.

\section{Evaluation of Marjory Gordon's patient functional health patterns}

The APRIDE (nursing diagnoses prioritisation algorithm (algoritmo de priorización de diagnósticos enfermeros) ) $)^{12}$ tool was used. This system is designed to make the nursing evaluation process easier by using a standard assessment model and a subsequent prioritisation of the diagnoses found (Table 1).

Pattern 2 was prioritised (nutritional-metabolic pattern) along with the NANDA (00046) diagnosis: impaired skin integrity related to mechanical factors, shown by a tissue wound, for being a patient that needs daily nursing care with a highly complex wound that requires maximum vigilance.

According to the functional pattern nursing evaluation, the nursing diagnoses, indicators, interventions and main activities were prioritised, as per the online tool NNNConsult ${ }^{13}$, which enabled the standardised languages developed by NANDA International, the results of the NOC, the interventions of the NIC and links between them to be quickly consulted (Figure 1 and Table 2).

\section{Development}

When the inmate was admitted (11 October 2016), he presented a left thoracic cavity or window of $20 \mathrm{x}$ $10 \mathrm{~cm}$, with sloughs and granulation tissue in good condition, but without the possibility of surgical closure of the cavity due to the major risk of severe infection in view of the comorbidity and history. Prior to entering prison, the dressings were carried out at the Jumilla Health Centre (Murcia). He was admitted to the Surgery Service of the HUVA, from where he returned in December 2016. Figure 2 shows graphic images of the progress, of the way the dressings are applied, and of the size of the wound when he was admitted and one year after.

The care protocol when the patient was admitted consisted of applying seven swabs with an antiseptic: internally applied $10 \%$ povidone iodine. In the hospital, treatment was applied by washing with hydrogel in solution (Protosan ${ }^{\circledR}$ ) and in October 2016 the treatment was changed to a wash with physiological saline solution and a sponge with soapy chlorhexidine to clean the cavity of the slough and exudate from the application of silver sulphadiazine cream (Flammazine cerio $\left.{ }^{\circledR}\right)$. The lung was not rubbed but dried and hydrofibre dressings with ionic silver (Aquacel Plata $\left.{ }^{\circledR}\right)$ dampened with saline solution or transparent hydrogel $\left(\right.$ Nugel $\left.^{\circledR}\right)$ were applied to the lung, to prevent continuous exposure of the silver sulphadiazine to the lung. It was dried and three swabs filled with half a swab impregnated with silver sulphadiazine were applied. The side of the compress with silver sulphadiazine was placed in contact with the thoracic wall and the diaphragm (one in the anterior and diaphragmatic region, another in the superior and anterior area, and another posterior). Two or three rolled compresses were applied separately on the hole in the wall, and the ends of the three swabs were folded on top.

Table 1. Prioritisation stage of the diagnoses obtained.

\begin{tabular}{lcccc}
\hline Main diagnostic tag & Impacts & Type diagnosis & Domain/clase & Total points \\
\hline 00099 - Ineffective health maintenance & 8 & Real & D01C2 & 226 \\
\hline 00146 - Anxiety & 10 & Real & D09C2 & 188 \\
\hline 00046 - Impaired skin integrity & 3 & Real & D11C2 & 100 \\
\hline 00114 - Relocation stress syndrome & 9 & Real & D09C1 & 170 \\
\hline
\end{tabular}




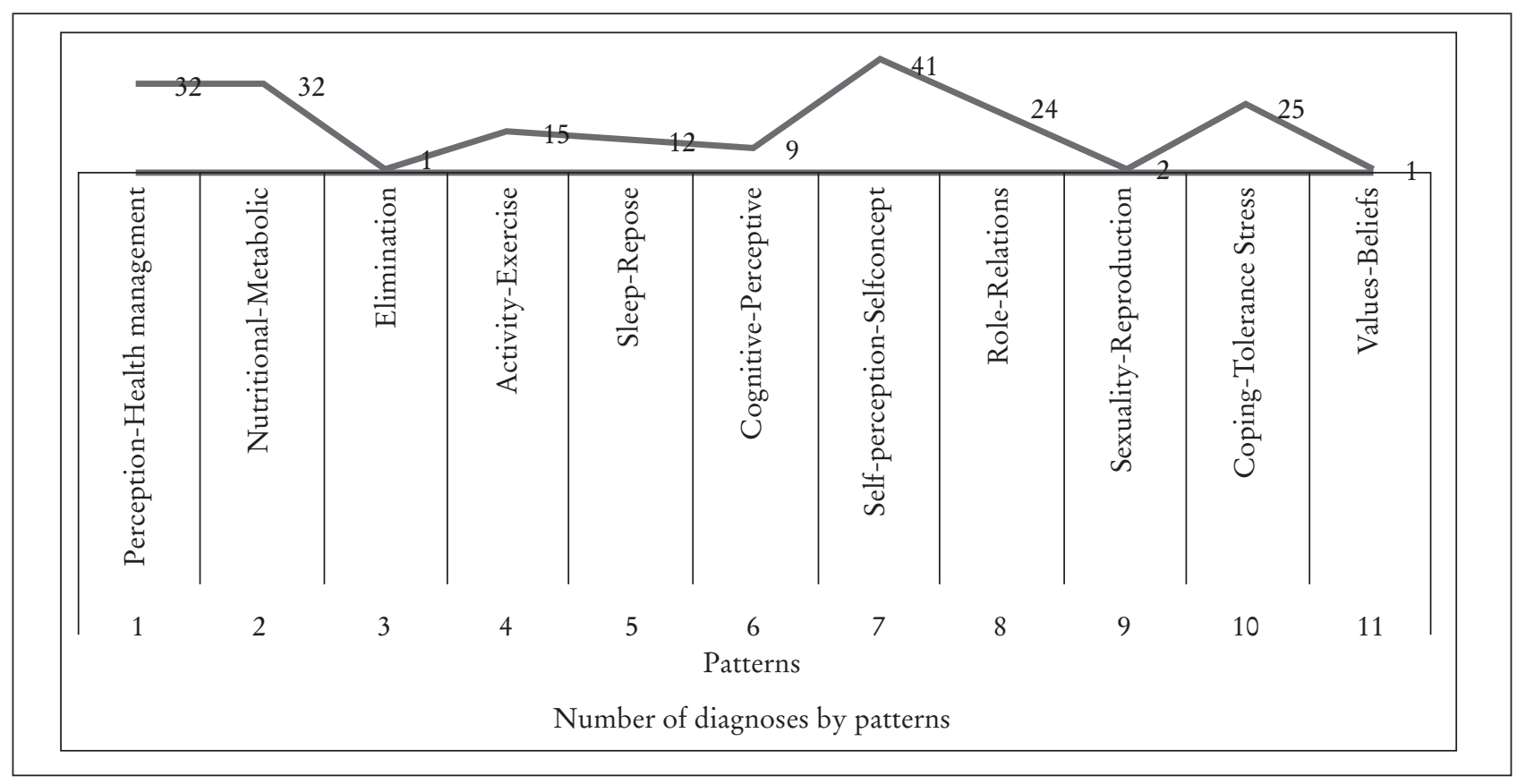

Figure 1. Number of diagnoses by patterns.

On 5 April 2017, the inmate presented self-limited bleeding. Treatment was applied for three alternate days, with a wash with physiological saline solution and chlorhexidine, and a dressing of Linitul ${ }^{\circledR}$ with sterile vaseline was applied, open over the entire inner and exterior surface of the wound, without requiring Aquace ${ }^{\circledR}$ or Flammazine ${ }^{\circledR}$, so as to prevent continuous rubbing on the granulation tissue. Swabs were then applied to the wound. The bleeding improved with Flammazine ${ }^{\circledR}$.

On 26 May 2017, the inmate presented an ulcerative wound, non-exudative, that made an impact because it was on the pulmonary bed, next to the bronchial plane (did not present air leak). Smears were for micro-bacteria. The treatments were maintained on alternate days $\left(\right.$ Linitul ${ }^{\circledR} /$ Flammazine $\left.^{\circledR}\right)$. He presented an orifice in the anterior hiliar area, with an appearance leading to suspicions of a bronchial fistula from tuberculosis. A positive result for several bacteria was obtained and the PCR was positive for M. tuberculosis, and so the patient was once again admitted to hospital. A new smaller fistulous orifice at about $2 \mathrm{~cm}$ from the anterior was seen, likewise in the hiliar area. No leaks were present after checking with saline solution (orifice with a caseous appearance). He followed treatment with respiratory isolation. The wound treatment was changed to washing with a chlorhexidine and saline solution sponge and washing with rifampicin (a vial diluted in $250 \mathrm{ml}$ of physiological saline solution). It was left for 5 minutes and removed with compresses. The Aquacel Plata ${ }^{\circledR}$ dressing was applied to pulmonary bed, three half compresses with cerio ${ }^{\circledR}$, covering the inner surface of the thoracic wall, and vaseline on the edges of the skin around the thoracostomy.

In June 2017, the inmate returned to the Murcia I Prison and in September the fistulous orifices closed with a minimum of fibroid exudate. Treatment was modified with the application of an alginate dressing without silver on the pulmonary bed. The wound had a good appearance. In October treatment was carried out with Flammazine ${ }^{\circledR}$ on alternate days, coinciding with the alginate treatment. On the days without Flammazine $^{\circledR}$, treatment was applied with Aquacel ${ }^{\circledR}$. In November, the inmate presented a local infection from Pseudomonas aeruginosa. In December, the inmate's wound progressed favourably, and presented an epithelisation of the edges of the thoracostomy with the alternative treatment method currently being applied. The size of the wound is $5 \times 12 \mathrm{~cm}$. The fistulous orifices have closed, the patient is stable in treatment, with constant monitoring by nursing staff.

Efforts were made to clarify and clear up any queries that the patient had, and he was informed of the changes observed, and of the type of treatment applied, thereby obtaining a good atmosphere of trust. 
Table 2. Nursing diagnoses, objectives or results and activities.

\begin{tabular}{|c|c|c|c|c|}
\hline $\begin{array}{l}\text { NANDA } \\
\text { diagnoses }\end{array}$ & $\begin{array}{l}\text { Expected outcomes } \\
\text { NOC }\end{array}$ & Main indicators & $\begin{array}{l}\text { Interventions } \\
\text { NIC }\end{array}$ & Main activities \\
\hline $\begin{array}{l}\text { 2-Pattern:nutritional- } \\
\text { metabolic. } \\
\text { (00046) Impaired skin } \\
\text { integrity related to } \\
\text { mechanical factors, } \\
\text { shown by tissue } \\
\text { wound. }\end{array}$ & $\begin{array}{l}\text { (1103) Wound healing: } \\
\text { secondary intention. } \\
\text { Initial score: } 1 . \\
\text { Daily score: } 5 . \\
\text { Expected time: during stay } \\
\text { in prison. }\end{array}$ & $\begin{array}{l}\text { (110321) Decreased } \\
\text { wound size. } \\
\text { Scale value: } 3 \text {, } \\
\text { moderate. } \\
(110301) \\
\text { Granulation. } \\
\text { Scale value: } 3 \text {, } \\
\text { moderate. }\end{array}$ & $\begin{array}{l}(3660) \text { Care } \\
\text { of thoracic } \\
\text { window. } \\
(3590) \\
\text { Inspection of } \\
\text { skin. }\end{array}$ & $\begin{array}{l}\text { (366007) Monitor } \\
\text { characteristics of wound. } \\
\text { (366006) Observe ulcers, } \\
\text { bleeding, sloughing, } \\
\text { secretions, colour, size, smell. } \\
\text { ( } 366014) \text { Describe } \\
\text { interventions carried out. } \\
\text { Daily treatment of wound as } \\
\text { per protocol. }\end{array}$ \\
\hline $\begin{array}{l}\text { 7-Pattern: self } \\
\text { perception-self } \\
\text { concept. } \\
\text { (000146) Anxiety } \\
\text { related to threat of loss } \\
\text { of health, shown by } \\
\text { confusion, concerns } \\
\text { expressed due to } \\
\text { changes in vital events } \\
\text { and insomnia. }\end{array}$ & $\begin{array}{l}\text { Expected time: during stay } \\
\text { in prison. } \\
\text { (1302) Coping. }\end{array}$ & $\begin{array}{l}\text { (130203) Verbalises } \\
\text { sensation of control. } \\
\text { Scale value: } 3 \text {, } \\
\text { sometimes shown. }\end{array}$ & $\begin{array}{l}(5230) \text { Coping } \\
\text { enhancement. } \\
\text { (5820) Anxiety } \\
\text { reduction. }\end{array}$ & $\begin{array}{l}\text { (523017) Help patient to } \\
\text { identify the information } \\
\text { that he is most interested in } \\
\text { obtaining. } \\
\text { (582005) Encourage patient to } \\
\text { express feelings, perceptions } \\
\text { and fears. } \\
\text { (582012) Listen attentively. }\end{array}$ \\
\hline
\end{tabular}

Daily score: 5 .

Expected time: during stay in prison.

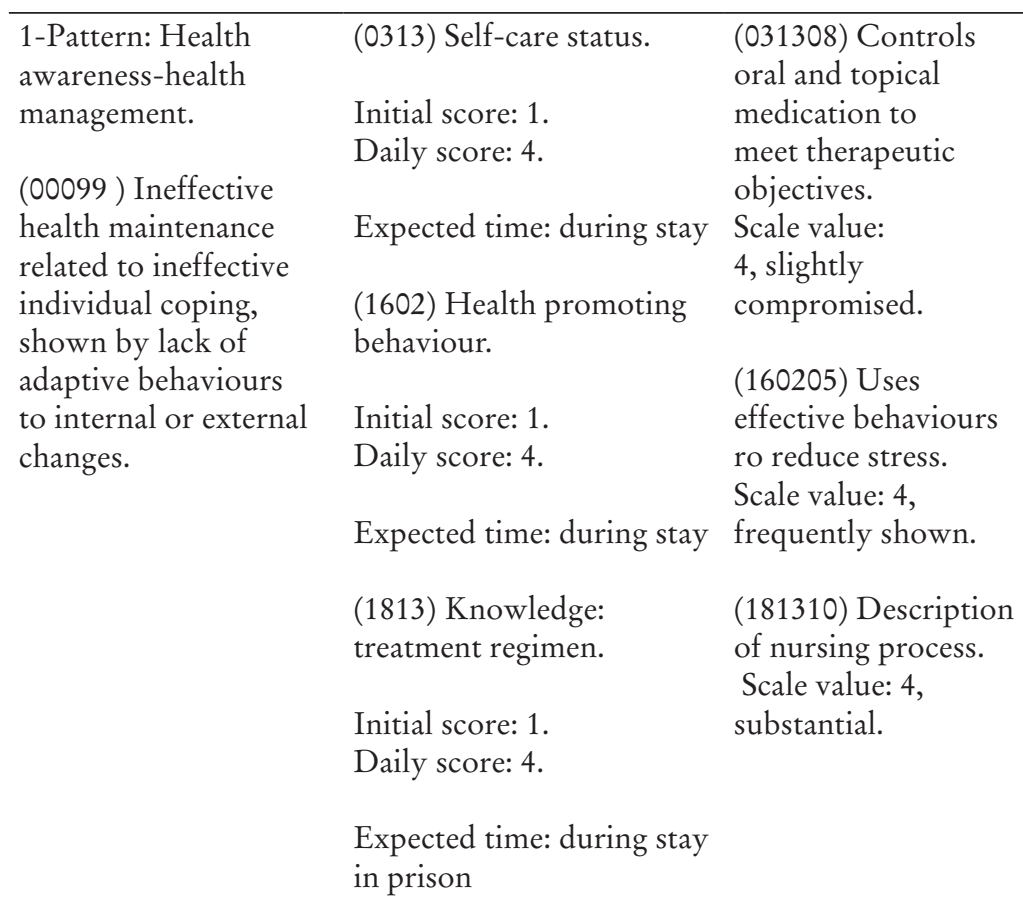
(2380)
Medication management.
(4470)
Reinforcement of self-directed change.
(5230) Coping enhancement.
(5602) Teaching: disease process.
(238009) Determine what drugs are needed and administer as per medical prescription and/or the protocol. (447007) Encourage the patient to examine personal values and beliefs and satisfaction with same. (523002) Encourage patient find a realistic description of the change of role. (523006) Encourage a realistically hopeful attitude as a way to manage feelings of impotence. (560203) Comment on changes in lifestyle that may be necessary to prevent future complications and/or control the disease process.

Note. NANDA: North American Nursing Diagnosis Association. NIC: Nursing Interventions Classification. NOC: Nursing Outcomes Classification. 


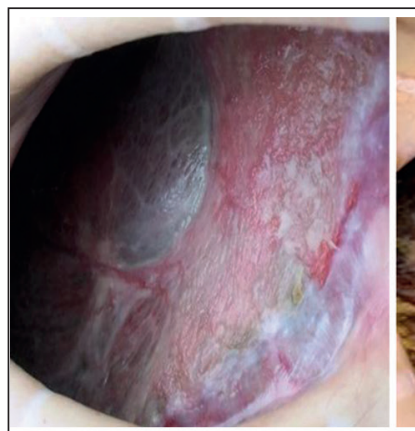

1. Haematic areas.

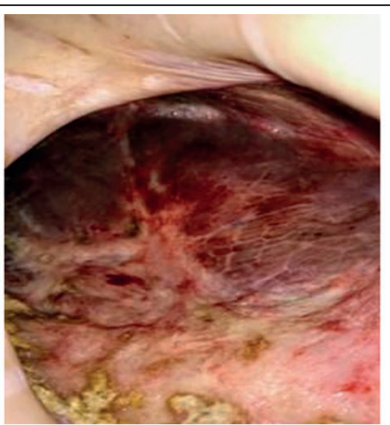

2. Fistulous bronchial orifice.

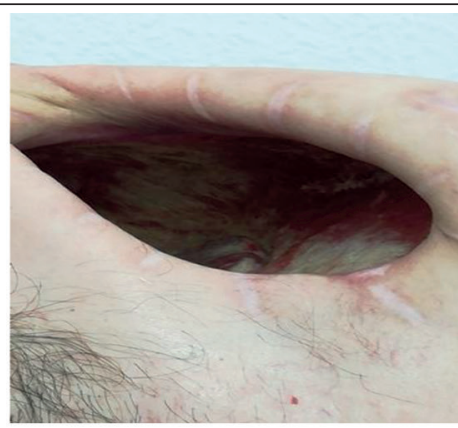

3. One month after admission $(20 \times 10 \mathrm{~cm})$.

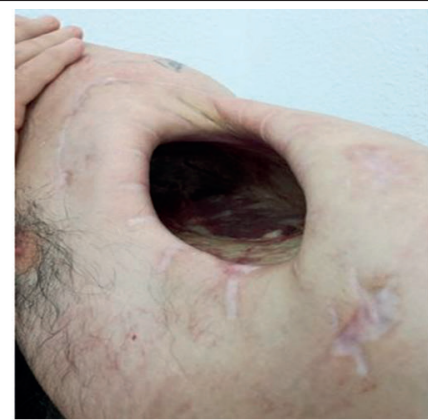

4. One year after admission $(5 \times 12 \mathrm{~cm})$.

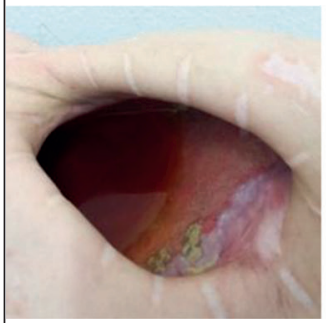

5. Washing with Rifaldín ${ }^{\circledR}$.

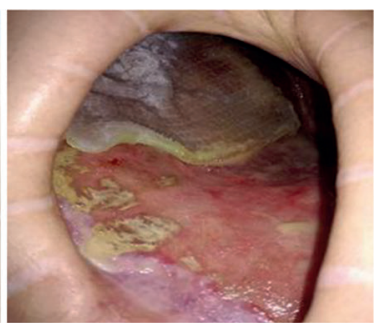

6. Application of alginate dressing.

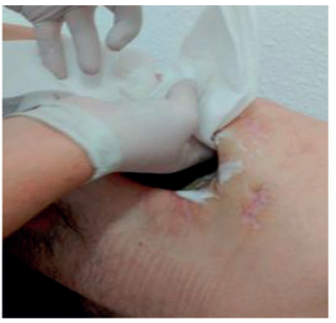

7. Application of

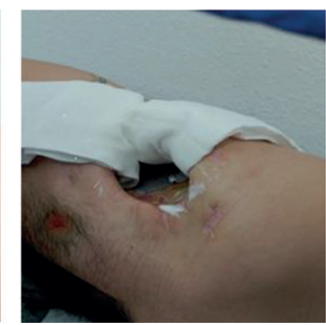

8. Tetra on thoracic walls.

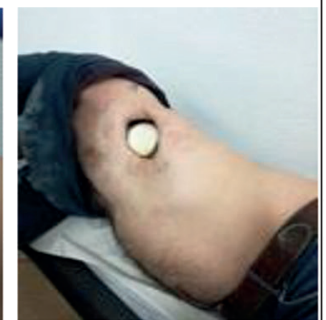

9. Occlusion of wound.

Figure 2. Photographs of progress of wound.

\section{DISCUSSION}

The indicators in the altered patterns were: nutritional-metabolic (reduction of wound and granulation). Within a Likert scale, with ranks from 1 to 5 , they passed from 1 to 3 (from "none" to "moderate”). The self-perception/self-concept (verbalised anxiety and sensation of control) changed from 1 to 3 (from "none to moderate" and from "never shown" to "sometimes shown"). Health awareness/health management (controls oral and topical medication to meet therapeutic objectives, uses effective behaviours to reduce stress, and description of the process of the disease) changed from 1 to 4 (from severely compromised to slightly compromised, from never demonstrated to almost always demonstrated and from none to substantial). All the changes were determined at the end of one year.

The NOC results were: wound healing (from 1 to 3 ), level of anxiety (from 3 to 4 ), coping with problems (from 3 to 4), self-care level (from 2 to 4), health promotion (from 2 to 4 ), therapeutic regimen (from 2 to 4$)$. All the changes were determined after one year of monitoring.
The inmate presented multi-pathology and was a highly complex patient that required constant monitoring and daily evaluation by nursing professionals, to establish if referral to more specialised healthcare resources was necessary ${ }^{6,14}$. Nurses should refer patients attended in their field of competence to other services ${ }^{15}$ and establish more direct communication to bring about more involvement on their part when preparing nursing reports, in which they comment on their evaluations, monitoring and interventions, using their own nursing language.

Daily care of a wound is a process carried out by nursing staff as a practice in their daily activities. The aim with this specific case is to demonstrate that is not just an isolated activity; the patient should receive comprehensive management, not only focusing on the reason for the consultation, but also assessing the different functional patterns in order to establish which have changed so as to take the evolution of the process into account, and provide better care and improved quality of life for the patient ${ }^{16}$. If the inmate's care is comprehensively addressed, a climate of trust can be created, enabling the patient to adapt to difficulties and reduce anxiety, which are very necessary factors for curing a wound. 
After daily contact, the patient's wound progressed satisfactorily, the patient showed better adaptation to the clinical situation and his confidence in a possible positive outcome increased. The nursing methodology applied to the patient enabled the following observations to be made: he accepted the changes to his body image, his fear about coping with the situation diminished and, to sum up, management of his own health improved.

\section{CORRESPONDENCIA}

M Carmen Martín-Cocinas Fernández

Centro Penitenciario Murcia I

E-mail:martinco62@hotmail.com

\section{REFERENCES}

1. Mederos Curbelo ON, Olewasegun Abiodun A, Mederos Trujillo OL, Ortega Barrera JC, Castellanos González JA. Ventana torácica y anestesia local en la supuración pleural. Rev Cubana Cir. 2016;55:30-9.

2. Ykehara M, Lupe R, Olivera A, Mercedes J, Castañeda Saldaña E. Ventana torácica en el tratamiento del empiema pleural crónico en el Hospital Nacional Cayetano Heredia, 1990-1998. Rev Med Hered. 2002;13:90-8.

3. Calvo JM, Lima EM. Neumotórax espontáneo secundario a tuberculosis pulmonar activa. Semergen. 2006;32:422-23.

4. Freixinet J, López L, Rodríguez de Castro F, Hussein M, Quevedo S, Hermosa MJ. Neumotórax espontáneo primario. Estudio retrospectivo sobre 495 casos. Arch Bronconeumol. 1995;31:276-9.

5. Molina M, Ortega N, Valiente B, Vera V. Neumotórax espontáneo y tuberculosis pulmonar activa. An Med Interna. 2001;18:149-51.

6. Blanco S, Herránz N, González-Penas N, Rial G, Guillén V, Pacheco R. Cuidados enfermeros del paciente con ventana torácica. Metas Enferm. 2009;12:64-7.

7. Alfaro-LeFevre R. Aplicación del proceso enfermero: guía paso a paso. $4^{a}$ ed. Madrid: Springer Science \& Business Media; 1998.
8. Brito PR, De Armas JM, Crespo-Gómez A, Aguirre A. Factores asociados al incremento en el uso de la metodología enfermera en Atención Primaria. Enferm Glob. 2011;10:189-99.

9. Real Decreto $1093 / 2010$, de 3 de septiembre, por el que se aprueba el conjunto mínimo de datos de los informes clínicos en el Sistema Nacional de Salud. BOE. 16 Sep 2010;225:78742-67.

10. Colon L. Los Patrones funcionales de Marjory Gordon. [Internet]. Enfermeria a la Vanguardia Blog. 2010. [citado 12 Ene 2018]. Disponible en: http://luzcolonenfermeria.blogspot.com. es/2010/06/los-patrones-funcionales-de-marjory. html

11. NANDA Internacional. Herdman T, Kamitsuru S, editores. Nursing Diagnosis: Definitions and Classification. 2018-2020. 11th ed. Thieme; 2017.

12. Resultados de la Valoración en APRIDE. [Internet; citado 15 Ene 2018]. Disponible en: https:// www.apride.es/result.php?to $=426$

13. NNNConsult. [Página web]. Londres: ELSEVIER; 2018. [citado 12 Ene 2018]. Disponible en: https://www.nnnconsult.com/nanda/46

14. Planes de Cuidados de Enfermería en Atención Especializada: Estandarización en Extremadura. [Internet]. Issuu. [citado 17 Ene 2018]. Disponible en: https://issuu.com/lusansolis/docs/libro_ planes_especializada/161

15. Análisis de la situación y propuestas de reforma de la enfermería de Atención Primaria en Asturias. [Página web]. Oviedo: Sociedad de Enfermería de Atención Primaria de Asturias (SEAPA); 2004. [citado 11 Jul 2018]. Disponible: http://docplayer. es/24722648-Seapa-sociedad-de-enfermeria-deatencion-primaria-asturias.html

16. Rivera Blanco AI, Salguero Matamoros FJ, Vargas Martínez AM, Rodríguez Pardo D, Torres Hidalgo G, Lozano Llamazares P. Cuidados de enfermería desde Atención Primaria a un paciente con ventana torácica. En: II Congreso Internacional y VIII Congreso Nacional de la Asociación de la Enfermería Comunitaria. Barcelona: 16-18 May 2012. [citado 17 Ene 2018]. Disponible en: https://www.geyseco.es/aec2012/images/fotosg/ tabla_165_C0191.pdf 